\title{
Integrated Reporting and Investor Clientele
}

\section{Citation}

Serafeim, George. "Integrated Reporting and Investor Clientele." Harvard Business School

Working Paper, No. 14-069, February 2014. (Revised April 2014.)

\section{Permanent link}

http://nrs.harvard.edu/urn-3:HUL.InstRepos:12111355

\section{Terms of Use}

This article was downloaded from Harvard University's DASH repository, and is made available under the terms and conditions applicable to Open Access Policy Articles, as set forth at http:// nrs.harvard.edu/urn-3:HUL.InstRepos:dash.current.terms-of-use\#OAP

\section{Share Your Story}

The Harvard community has made this article openly available.

Please share how this access benefits you. Submit a story.

Accessibility 
H A R V A R D

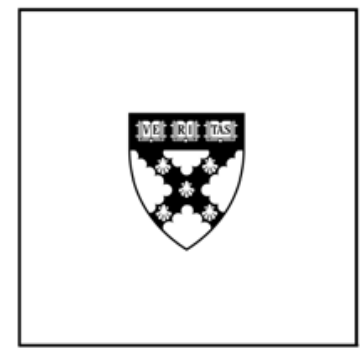

\section{Integrated Reporting and Investor Clientele}

George Serafeim

\section{Working Paper}

14-069

April 4, 2014 


\title{
Integrated Reporting and Investor Clientele
}

\author{
George Serafeim*
}

Harvard Business School

\begin{abstract}
In this paper, I examine the relation between Integrated Reporting (IR) and the composition of a firm's investor base. I hypothesize and find that firms that practice IR have a more long-term oriented investor base with more dedicated and fewer transient investors. This result is more pronounced for firms with high growth opportunities, not controlled by a family, operating in 'sin' industries, and exhibiting more stable IR practice over time. I find that the results are robust to the inclusion of firm fixed effects, controls for the quantity of sustainability disclosure, and alternative ways of measuring IR. Moreover, I show that investor activism on environmental or social issues or a large number of concerns about a firm's environmental or social impact leads a firm to practice more IR and that this investor or crisis-induced IR affects the composition of a firm's investor base.
\end{abstract}

Keywords: integrated reporting, sustainability, disclosure, investor clientele, investor activism, corporate reporting

\footnotetext{
${ }^{*}$ George Serafeim is an Assistant Professor of Business Administration at Harvard Business School. I recognize financial support from the Division of Research and Faculty Development of Harvard Business School. I am grateful for many valuable comments from Gavin Cassar, Bob Eccles, Gilles Hillary, Steve Monahan, Grace Pownall, Shiva Rajgopal and seminar participants at Emory University, INSEAD and the spring accounting camp at Tilburg University. I am solely responsible for any errors. I am grateful for research assistance from Andy Knauer and James Zeitler. Contact email: gserafeim@hbs.edu.
} 


\section{Introduction}

Integrated Reporting (IR) is a relatively new phenomenon in the world of corporate reporting that has gained significant momentum in the last ten years. The International Integrated Reporting Council (IIRC) defines IR as "a process founded on integrated thinking that results in a periodic integrated report by an organization about value creation over time and related communications regarding aspects of value creation. An integrated report is a concise communication about how an organization's strategy, governance, performance and prospects, in the context of its external environment, lead to the creation of value in the short, medium and long term." Its pilot program included, as of 2013, more than 100 large multinational companies supported by an investor network with more than 40 members with the IIRC defining long-term investors as the primary audience for IR. For example, in the US, Pfizer, American Electric Power, Clorox and Southwest Airlines have self-labeled their reports as integrated. Many more though integrate sustainability data in their financial reports, while not labeling them as integrated. ${ }^{1}$ While more companies are increasingly practicing some type of IR and more investors are starting to use the reported data we still have a very limited understanding of the effects of IR.

In this paper, I investigate the relation between IR and the composition of a firm's investor base. Specifically, I hypothesize and test whether firms that practice IR tend to have more dedicated investors and less transient investors, and as a result a more long-term oriented investor base. Anecdotal evidence suggest that such a link could exist. For example, American Electric Power, one of the first companies in the US to self-declare its report as integrated, exhibits an investor base that is characterized by lower portfolio turnover relative to competitors, such as AES Corporation. Similarly, the institutional investors of Dow Chemical, a company that has long integrated sustainability data in its annual report, exhibit low portfolio turnover relative to those of Monsanto, a competitor in agricultural solutions. Moreover, practitioners argue that the attraction of long-term investors is a consequence of adopting IR. While

\footnotetext{
${ }^{1}$ Sustainability data usually refer to environmental, social and governance data, such as employee turnover and satisfaction, product quality metrics, water and energy consumption, training of employees in anticorruption procedures etc.
} 
anecdotal evidence suggest the presence of a link and many practitioners argue for its existence, no empirical evidence have been provided to establish such a relation.

IR comes as a response to criticisms that disconnected financial and sustainability reporting are not effective in describing the long-term value creation process inside the organization. Proponents of IR argue that companies should supplement the financial information they are required to report based on accounting standards with other nonfinancial information that is of interest to shareholders, such as on customers, employees, and the environment. Common reasons cited by those making this argument include: (1) financial information is a lagging indicator, a "rear-view mirror" of the company's performance, (2) nonfinancial information can provide insights into the company's expected future financial performance, and (3) for most companies their market value exceeds their book value so additional reporting can provide information on a company's intangible assets that are not captured on the balance sheet. ${ }^{2}$

Similarly, proponents of IR argue that separate sustainability reporting, although providing relevant information for multiple stakeholders, is unlikely to be an effective mechanism to communicate to investors a firm's performance on environmental and social issues and how they relate to financial performance (Eccles and Krzus 2010). The argument goes that in sustainability reports the data are not placed in the context of a company's strategy and business model, are less credible and timely compared to the financial data that are audited at a higher level of assurance and are released sooner, and the concept of materiality is not effectively addressed. Therefore, while sustainability data are argued to be value relevant, the aforementioned factors impede their decision usefulness from an investor perspective.

Many commentators have argued that because IR could be a more effective mechanism to communicate a firm's capacity to create value in the long-term, firms that practice IR might find themselves to look more attractive to long-term investors. However, whether IR indeed is a more effective managerial tool to communicate a firm's long-term prospects is an open empirical question and no evidence have been

\footnotetext{
${ }^{2}$ Robert Eccles, "The Performance Measurement Manifesto," The Harvard Business Review, v. 69, is. 1, 1991, p. 131-137. See also Robert Eccles, Robert Herz, Mary Keegan, and David Phillips. The Value Reporting Revolution: Moving Beyond the Earnings Game. (New York: John Wiley \& Sons, Inc., 2001).
} 
provided to support these claims. Therefore, I seek to provide empirical evidence on whether firms that practice IR tend to have a more long-term oriented investor base.

My interest in this relation originates from the fact that the type of investors that own the shares of a firm can affect managerial decision-making and corporate value. ${ }^{3}$ For example, Bushee (1998) finds that managers are less likely to cut $R \& D$ to reverse an earnings decline when institutional ownership is high, but a large proportion of ownership by transient investors significantly increases the probability that managers reduce R\&D to reverse an earnings decline. Similarly, Matsumoto (2002) documents that firms with higher presence of transient investors are more likely to avoid negative earnings surprises through earnings and expectations management. Chen, Harford and Li (2007) show that long-term investors are effective monitors and their level of holdings is positively related to post-merger performance and the withdrawal probability of bad bids. Gaspar, Massa and Matos (2005) show that firms with high levels of short-term investor holdings have lower bid premiums and larger post-acquisition underperformance consistent with weaker monitoring allowing managers to proceed with value-reducing acquisitions or to bargain for personal benefits against shareholder returns. Zahra, Neubaum and Huse (2000) show that high levels of dedicated investors are associated with higher levels of corporate entrepreneurship while high levels of transient investors are associated with lower levels. These results collectively indicate that transient institutional investors encourage myopic investment behavior and earning management; in contrast, ownership by dedicated investors serves to reduce pressures on managers for myopic investment behavior.

The analytical model of Bolton, Scheinkman, and Xiong (2005) yields similar results. They model a capital market with overconfident investors where stock prices have two components: a long-run fundamental value and a short-term speculative component. They show that in times of great heterogeneity in investor beliefs the optimal incentive contract is designed by investors to partially or completely induce

\footnotetext{
${ }^{3}$ For a discussion see Drexel University Center for Corporate Governance Roundtable on Risk Management, Corporate Governance, and the Search for Long-term Investors. 2010. Journal of Applied Corporate Finance 22 (4): 58-74.
} 
the CEO to pursue a strategy that maximizes the speculative component by pursuing short-term speculative projects even at the expense of long-run fundamental value. Critically, the more long-term oriented shareholders are, the less likely they are to encourage managers to engage in short-termist behavior. Practitioners also argue for a link between a firm's investor base and managerial decision making, with many corporate executives and board members fearing that short-term investors encourage short-termism and affect adversely long-term financial performance (Barton and Weisman 2014). As a result of the evidence above, many executives are beginning to actively seek long-term investors.

I construct a sample of 1,114 unique US-listed firms, for which I have data both on the degree of IR practice and the investor base, between 2002 and 2010. I find that more IR is associated with a more long-term investor base, defined as the difference in the percentage of shares held by dedicated and transient investors. This result holds after controlling for other known determinants of the type of investors owning shares in a firm. Moreover, the results remain unaffected when I control for the quantity of sustainability metrics disclosed by a firm, whether a company issues a sustainability report, follows Global Reporting Initiative (GRI) guidelines, and the economic, environmental, social, and governance (EESG) performance of the firm. Therefore, the effect of IR on investor base is incremental to a firm's sustainability reporting practices and the level of its EESG performance.

I conduct a battery of tests to address potential empirical biases. Specifications that replace industry with firm fixed effects yield very similar results suggesting that a firm-persistent correlated omitted variable cannot explain the association between IR and investor base. Changes models that lag either changes in IR or changes in investor base composition suggest that lagged IR change is correlated with future changes in investor base, although the statistical significance of the association is moderate. I find no significant association between lagged changes in investor base and future IR changes suggesting that reverse causality where a more long-term investor base forces a firm to practice more IR is unlikely to be the source of the documented association between the two constructs.

I show that the strength of the effect of IR on investor clientele is moderated by several variables. First, I find some evidence that firms with higher price-to-book ratios and as a result more growth 
opportunities exhibit a stronger relation between IR and investor clientele, consistent with IR communicating information that is valuable for assessing the long-term prospects of a business; information that is needed more for firms with high growth opportunities. Second, I find that the relation is stronger for firms that are not family controlled. Because family firms have been shown to exhibit a long-term orientation and a better performance on environmental and social metrics (Le Breton-Miller and Miller 2006), one can think about IR and family ownership as substitute signals of a firm's ability to integrate sustainability considerations in the business. Third, the relation between IR and investor clientele is stronger in industries that are under severe pressure from regulation and shifting social expectations. Probably the best example of companies under such pressure are firms operating in 'sin' industries such as alcohol, firearms, and tobacco. I find that for these firms there is a stronger relation between IR and investor clientele. Finally, consistent with accounting theories that emphasize the importance of commitment in disclosure (Leuz and Verrecchia 2000) I find that the relation between IR and investor clientele is negatively moderated when firms have exhibited in the past high volatility in their IR practice.

In addition, I exploit two events to understand how they influence IR and the subsequent composition of a firm's investor base. First, using KLD data I identify firms that experience a sustainability crisis as companies that have a large number of environmental, human rights, product, diversity, and employee related concerns. Past research has shown that these crises serve as a catalyst for firms to engage with sustainability and become more transparent about their environmental or social impact (Eccles, Miller and Serafeim 2012). I show that firms that have a large number of such concerns subsequently practice more IR and the predicted component of this increased IR is related to a more long-term investor base in the future. I also conduct an analysis to understand the role of investor activism on social and environmental issues. I collect data on all shareholder resolutions filed for US-listed companies related to social and environmental issues and find that firms for which investors file shareholder resolutions on these issues increase their IR score and that this increase in IR is associated with an increase in long-term investor base. This result suggests that investor engagement is an effective mechanism of promoting IR. 
In additional tests, I separately estimate the effect of IR on dedicated and transient investors to understand which investor type is driving the results. I find a consistently significant association between dedicated investors and IR, with firms that practice more IR having a higher percentage of their shares held by dedicated investors. I find a negative coefficient on IR when the dependent variable is the percentage of share held by transient investors but it obtains significance only in some specifications. An interpretation of this result is that firms practicing IR not only attract dedicated investors but also in some cases become unattractive for transient investors. Importantly, I find that investor-induced IR from shareholder engagement increases the percentage of shares held by dedicated investors but it does not affect the percentage of shares held by transient investors. This is in contrast to crisis-induced IR which does not affect the percentage of shares held by dedicated investors but it does reduce the percentage of shares held by transient investors.

I also test the robustness of the results to the use of an alternative IR variable provided by Sustainable Asset Management, the firm that constructs the Dow Jones Sustainability index. The variable measures whether environmental or social narrative information or key performance indicators are integrated in annual reports. Using this alternative variable for 2010 for a smaller sample of US firms, yields results that are similar to the main results. There is a positive association between IR practice and the percentage of shares held by long-term investors. In addition, I conduct a preliminary analysis that attempts to isolate the mechanism through which IR leads to a more long-term investor base. Specifically, I analyze the relative importance of increased relevance, reliability and timeliness of the sustainability data due to IR and find that primarily relevance and timeliness are the mechanisms that lead to a more long-term investor base.

This paper contributes to an emerging literature that seeks to understand the causes and consequences of sustainability and integrated reporting. Ioannou and Serafeim (2013) show that mandating sustainability reporting influences managerial practices and improves firms' environmental, social, and governance (ESG) performance. Cheng, Ioannou, and Serafeim (2014) find that firms with more sustainability disclosure face lower capital constraints and as a result better access to finance while Dhaliwal 
et al. (2011) find that firms with more sustainability disclosure have lower cost of equity capital. This paper documents that integrating sustainability information within the financial reporting context shifts the investor clientele of a firm towards dedicated and away from transient investors.

Moreover, the paper contributes to the literature that examines how companies cater to different types of investors. Bushee and Noe (2000) find that firms with higher disclosure rankings attract more transient investors. They attribute this to the increase in stock liquidity which makes the company more attractive to transient investors. Their emphasis is on transient investors while I concentrate primarily on the direct effect of IR on dedicated investors. Brochet, Loumioti, and Serafeim (2013) show that firms communicating more long-term information during their conference calls have a more long-term oriented investor base and are followed by sell-side analysts that are more likely to issue long-term forecasts. I find that IR is a corporate reporting innovation that serves as an important determinant of the composition of a firm's investor base.

The remaining of the paper proceeds as follows. Section 2 presents the hypothesis development. Section 3 describes the sample and the data used in this study. Section 4 describes the results. Section 5 concludes.

\section{Hypothesis Development}

Information asymmetry between managers and investors present frictions in the capital allocation process restricting access to finance for corporations (Hubbard 1998). The higher the information asymmetry the more likely it is that investors will ask for a risk premium as a reward for allocating capital to companies under incomplete information (Merton 1987). Moreover, the higher the information asymmetry the higher are the costs of monitoring for institutional investors further increasing frictions (Healy and Palepu 2001). However, investors differ on their time horizons with dedicated investors actively buying and holding stocks for longer periods of time compared to transient investors. Long-term investors are more likely to 
hold shares in companies that provide more information about their long-term prospects since for them the information is relevant in assessing the value of the firm and in monitoring management over time.

Sustainability information in the form of environmental and social data is a relatively new development that has been increasingly reported by a larger number of firms around the world. Not only the number of companies reporting sustainability information but also the number of investors using this information has been increasing. The number of signatories to the United Nations Principles for Responsible Investment (UNPRI) has increased from 100 in 2006 representing \$4 trillion in assets under management to 1,188 in 2013 representing \$34 trillion (Eccles and Serafeim, 2013). Investor interest in sustainability data is also evidenced by the large number of investors accessing sustainability data on Bloomberg terminals (Eccles, Krzus and Serafeim 2011). While sustainability data could be relevant over any timeframe, it is often argued that they are primarily informative about the long-term prospects of the business. Consistent with this idea it is primarily pension funds and investment arms of insurance firms, institutions with relatively longer time horizons, that have been the most frequent advocates for disclosure of sustainability data.

Research has shown that disclosure of sustainability data has economic effects. Yu, Du and Bhattacharya (2014) found abnormal stock price reactions around the disclosure of sustainability information. Cheng, Ioannou and Serafeim (2014) found that firms with better sustainability disclosure have lower capital constraints and better access to finance. Dhaliwal et al. (2011) showed that firms experience a decrease in cost of equity capital after issuing a sustainability report. Dhaliwal et al. (2012) found that the issuance of stand-alone sustainability reports is associated with lower analyst forecast error and that this relation is stronger in countries that are more stakeholder-oriented and for firms and countries with more opaque financial disclosure.

While the availability of sustainability data has been increasing, there have been several criticisms of their decision usefulness for investors. Perhaps, the most important criticism has been the lack of placing the data in the context of the strategy and the business model of the company as a result obscuring the relation between sustainability and financial performance (Eccles and Krzus, 2010). Closely linked is the 
criticism about the absence of an assessment of the materiality of the different sustainability issues. Surveys of institutional investors suggest that $73 \%$ of them disagree that sustainability reporting is linked to business strategy and risk, and 93\% disagree that sufficient information is provided to assess financial materiality (Eurosif and ACCA 2013). The lack of link to financial issues is also reflected in the creation of the Sustainability Accounting Standards Board (SASB) whose mission is to develop industry-specific guidance around materiality. Another criticism relates to the credibility of the data since separate sustainability reports frequently obtain 'Limited' assurance instead of 'Reasonable', if any assurance at all. Industry observers suggest that performing an audit of sustainability data is several orders less expensive compared to financial data, because of the lower level of assurance provided. Moreover, timeliness of the data is another concern because sustainability reports typically come out well after the financial reports of the firm. This timing discrepancy decreases the amount of investor attention with fewer investors reading sustainability reports. ${ }^{4}$

IR is a new form of reporting that attempts to mitigate all the above deficiencies. Investors seem to support IR. Eighty percent of investors surveyed believe that IR will be useful or very useful for increasing the reliability and relevance of sustainability information (A4S and GRI 2012). However, IR has a short history, its meaning is still evolving, and only recently has a framework been developed that can provide companies guidance on what constitutes an IR. Like other new management concepts, IR first started in practice. The first companies to produce a self-declared IR were the Danish enzymes company Novozymes (in 2002), the Brazilian cosmetics fragrances company Natura (in 2003), and the Danish pharmaceutical company Novo Nordisk (in 2004). ${ }^{5}$ Starting in 2010, all South African companies listed on the Johannesburg Stock Exchange were required to issue an IR or explain why they were not doing so. ${ }^{6}$

\footnotetext{
${ }^{4}$ See here for a discussion of the usefulness of ESG data for investors: https://www.globalreporting.org/information/events/conference2013/news/Pages/Updates/2-4.aspx

${ }_{5}^{5}$ One Report: Integrated Reporting for a Sustainable Strategy by Robert G. Eccles and Michael P. Krzus, John Wiley \& Sons, Inc. Hoboken, New Jersey, 2010, Chapter 1.

${ }^{6}$ Ibid., p. 164.
} 
There is no clear way to measure the number of companies that are issuing integrated reports. Rather the practice of IR is a matter of degrees. There are companies that are doing more or less IR and firms that practice to a certain extent IR while not describing their reports as integrated (Eccles and Serafeim 2011). For example, IRRC and SII (2013) found that among S\&P 500 companies only seven labeled their reports as integrated but almost all (499) made at least one sustainability related disclosure that was linked to financial performance. Similarly, $65 \%$ made a sustainability related disclosure in $10-\mathrm{K}$ with monetary estimates and $54 \%$ discussed product formulations to address sustainability challenges. The difficulty to identify IR and have a universally accepted definition of what constitutes an IR is reflected in the fact that through 2012 there were no guidelines on what constituted an IR with the exception of a brief document prepared in early 2011 by the Integrated Reporting Committee of South Africa. No formal guidance about integrated reporting existed until the International Integrated Reporting Committee (IIRC) published its "International $<\mathrm{IR}>$ Framework" ( $<\mathrm{IR}>$ Framework) in December 2013.

A central tenet of IR is placing the sustainability activities of a firm within the context of an organization's strategy and business model. Therefore, emphasis is given on the material sustainability issues that are most likely to affect the ability of an organization to create value in the future. Materiality is one of the guiding principles in the <IR> framework developed by the IIRC and its importance is reflected in the creation of SASB whose mission is to establish industry-based sustainability standards for the recognition and disclosure of material environmental, social and governance impacts by companies traded on U.S. exchanges. A complementary guiding principle is the connectivity of information; IR should show the interrelatedness and dependencies of the different factors that affect the value creation process inside an organization. ${ }^{7}$ Ninety-two percent of investors surveyed agreed or strongly agreed that financial and other sustainability information should be more integrated (Eurosif and ACCA 2013).

Increased relevance of the reported information is not the only potential benefit. IR could raise the credibility of the sustainability data since the information is now part of regulatory filings that are

\footnotetext{
${ }^{7}$ See http://www.theiirc.org/wp-content/uploads/2013/12/13-12-08-THE-INTERNATIONAL-IR-FRAMEWORK2-1.pdf
} 
scrutinized by regulators and to a greater extent by auditors. Including sustainability data in an annual report does not necessarily mean that the audit opinion provided for the financial numbers covers the sustainability data as well. ${ }^{8}$ However, the integrated reporting process has been shown to improve the credibility and accuracy of sustainability information due to an improvement in the management information systems and control procedures related to the sustainability data (Eccles and Krzus 2010). Many prior studies have shown that credible information is more likely to be used by investors. For example, Kallapur and Kwan (2004) examine the value relevance and reliability of brand assets recognized by UK firms, and the stock price reaction to the announcement of brand capitalization. They find that brand assets are value relevant, but the market capitalization rates of brands of firms with low contracting incentives are higher than those of firms with high contracting incentives to capitalize and overstate brand values. Investors perceive brand values disclosed by firms with high contracting incentives as less reliable and as a result impound them less in market prices.

Finally, with IR, sustainability data are reported on a timelier basis since they are disclosed at the same time as the financial data. While annual financial reports are often disclosed 90 days after the end of the financial year, sustainability reports are often disclosed 180 days after. ${ }^{9}$ This reporting lag makes sustainability data less timely potentially reducing their usefulness to investors. Past studies document the importance of timeliness to investors. For example, Givoly and Palmon (1982) show that the information content of earnings announcements decreases as the reporting lag increases. Collins et al. (1994) show that lack of timeliness in earnings explains the low contemporaneous relation between earnings and stock

\footnotetext{
${ }^{8}$ I collect data from the GRI website on firms' assurance practices. I find that for a sample of global companies that file their integrated or sustainability reports with the GRI, the probability of external assurance for the whole report is 45 percent higher for integrated reports. Moreover, the likelihood of 'Reasonable' assurance compared to 'Limited' assurance increases for firms issuing integrated reports. These results are obtained using logistic regressions with industry and country fixed effects for the years 2012 and 2013.

${ }^{9}$ I do not have data on the date of release of a sustainability or integrated report. However, I collected from the GRI website for a sample of global companies the date that companies file their report with the GRI. Controlling for industry and country fixed effects I find that integrated reports are filed on average 22 days earlier after the end of the financial year than sustainability reports.
} 
returns. A rich literature in accounting documents timeliness as an important qualitative characteristic of accounting information (Basu 1997).

Therefore, long-term investors, who are interested in relevant, credible, and timely information for assessing the long-term prospects of the firm, could be more likely to hold shares of firms that practice IR. These firms presumably provide information that is value relevant in the long-term, decreasing information asymmetry between interested investors and corporate managers thereby decreasing financing frictions and monitoring costs. Thereby, all else equal, I expect long-term investors will be attracted to firms that practice IR.

However, there are a number of reasons why this association might not exist. I separate the reasons to those that are conditional on the presence of sustainability reporting and those irrespective of sustainability reporting. First, independent of the presence of sustainability reporting, IR will not be associated with a more long-term investor base if sustainability data are not value relevant. In other words, if environmental and social performance are not related to financial performance then the environmental and social data are value irrelevant and most long-term investors will ignore them. ${ }^{10}$ If this is true then absent of controls for sustainability reporting there should be no relation between IR and the type of investor base. While debate still exists about what is the relation between sustainability and financial performance, nevertheless there is evidence that investors actually seek the data (Eccles, Krzus and Serafeim 2011), sellside analyst perceptions about the implications of sustainability performance on future financial performance have changed over time (Ioannou and Serafeim 2014), and that variation in sustainability disclosure across firms explains variation in access to finance (Cheng, Ioannou and Serafeim 2014), cost of capital (Dhaliwal et al. 2011), and analyst forecast errors (Dhaliwal et al. 2012). Moreover, other studies have shown that mandatory sustainability disclosure decreases information asymmetry (Hung, Shi and

\footnotetext{
${ }^{10}$ A relation between IR and type of investor base can still exist even if sustainability data are value irrelevant if many institutional investors use the data because of ethical reasons and not to maximize risk-adjusted performance. While there are certainly investors with ethical motives, their size and number is not likely to be enough to make a difference in my results.
} 
Wang 2013) and that voluntary sustainability disclosure generates abnormal stock returns around announcement (Griffin and Sun 2013).

Second, in the presence of sustainability reporting, IR will not be associated with a more long-term investor base if the provision of the sustainability data as a separate report is sufficient to decrease information asymmetry between interested investors and corporate managers and integration provides no benefit in terms of relevance, credibility and timeliness. If this is true then in the presence of controls for sustainability reporting there should be no relation between IR and investor base. This is plausible given the relatively underdeveloped state of IR in the US (Eccles and Serafeim 2011) and the fact that material sustainability risks and opportunities are rarely discussed in regulatory filings, namely $10-\mathrm{K}$, in the US (IRRC and SII 2013).

\section{Sample and Data}

To construct the sample I collect data on IR from Thomson Reuters ASSET4. ASSET4 is a division of Thomson Reuters that specializes in providing objective, relevant, auditable and systematic sustainability information and investment analysis tools to professional investors who built their portfolios by integrating sustainability data into their traditional investment analysis. It is estimated that investors representing more than $\$ 3$ trillion of assets under management use the ASSET4 data, including prominent investment houses such as BlackRock. Specially trained research analysts collect 900 evaluation points per firm, where all the primary data used must be objective and publically available. After gathering the data every year the analysts transform it into consistent units to enable quantitative analysis. The ASSET4 database has been used in prior studies to measure sustainability performance or disclosure (Ioannou and Serafeim 2012; Chen et al. 2013).

ASSET4 measures “a company's management commitment and effectiveness towards the creation of an overarching vision and strategy integrating financial and extra-financial aspects. It reflects a company's capacity to convincingly show and communicate that it integrates the economic (financial), 
social and environmental dimensions into its day-to-day decision-making processes." ASSET4 provides a score for a firm's IR ranging from zero to 100. This score is a composite index of different disclosures, such as whether the company "is reporting about the challenges or opportunities of integrating financial and extra-financial issues, and the dilemmas and trade-offs it faces", "explicitly integrates financial and extra-financial factors in its management discussion and analysis (MD\&A) section in the annual report", "has set targets or objectives to be achieved on the integration of ESG issues into its strategy and day-today decision making", and "explains how it engages with its stakeholders." I also use an alternative measure of IR using data from Sustainable Asset Management that I describe in the next section.

Between 2002 and 2010 ASSET4 included about 6,036 observations for US-listed firms with available data on investor holdings. I am able to collect all the necessary data to conduct the analysis for almost all firms and after requiring data on all variables, described below, the sample includes 5,726 observations. Average IR score in the sample is 39 with a standard deviation of 29 suggesting significant variation in the practice of IR (Table 1).

I collect data on types of institutional investors from Thomson Reuters Institutional Holdings. While ASSET4 is an international dataset, the institutional holdings data are available only for firms listed in the US, therefore the resulting sample includes only US-listed firms. The vast majority of sample firms are US with less than 5 percent being Canadian. Bushee (1998) classifies institutional investors in three types: transient, dedicated, and quasi-index. Transient investors have low holding periods, high portfolio turnover and a high number of holdings. Dedicated investors have large holding periods, low portfolio turnover and a more concentrated portfolio. Quasi-index investors have a portfolio that closely follows a stock market index with small deviations. I define a variable (LT Investor) that measures the extent that the investor base of a firm is tilted towards dedicated and away from transient investors as the difference between the percentage of shares held by dedicated and transient investors. Consistent with the literature, average LT Investor is negative (-6 percent) suggesting that more investors are transient rather than dedicated (Table 1). On average 9.4 percent of the shares are held by dedicated investors and 15.5 percent by transient. Quasi-index funds hold on average 46.8 percent of the shares of the firms in my sample. 
Apart from IR, I also collect data from ASSET4 on governance practices that have been shown to be associated with investor clientele (Bushee, Carter, and Gerakos 2009). Specifically, I collect data on whether the board of a company is classified ( 7 percent of the sample) or staggered (45 percent of the sample), and whether a supermajority vote is required to make decisions (32 percent of the sample). Moreover, I collect data on the percentage of quantitative sustainability metrics disclosed by a firm out of 121 metrics collected by ASSET4 (Disclosure Quantity), whether a firm issues a separate sustainability report (Sustainability Report), and whether the firm follows the GRI guidelines (GRI). The GRI guidelines are by far the most followed principles for sustainability reporting with over 2,000 companies around the world using them as of 2013. On average sample firms disclose 54 percent of the sustainability metrics followed by ASSET4, 21 percent of the firm-years have a sustainability report and 13 percent follow the GRI guidelines (Table 1). Controlling for the quantity of sustainability disclosure, whether the firm issues a sustainability report and follows GRI guidelines allows making inferences about the incremental association between IR and investor base that cannot be explained by a firm's supply of stand-alone sustainability data.

I collect from Worldscope a variety of accounting and stock market data that serve as control variables. I include in all specifications as controls a firm's size as measured by the natural logarithm of sales, leverage defined as total debt over total assets, earnings yield, book-to-market ratio, dividend yield, past one-year sales growth, equity beta, stock return volatility, and past one-year stock return. All these variables have been shown to be associated with the investor base of a firm (Bushee and Noe 2000). Table 1 presents summary statistics for all variables.

The final sample includes 1,114 unique firms and 5,726 observations between 2002 (the earliest year ASSET4 provides data) and 2010. In analyses where I include firm fixed effects I require at least four years of data for each firm in the sample to ensure that there is enough within-firm variation. Imposing this restriction decreases the sample to 649 unique firms and 4,684 observations.

Table 2 shows univariate correlations across all variables. Firms that practice more IR and firms with better EESG performance have a more long-term oriented investor base. While IR exhibits a positive 
relation with LT Investor, Disclosure Quantity, Sustainability Report, and GRI all exhibit a negative relation with LT Investor suggesting that the positive relation between IR and LT Investor is not reflecting just a positive relation between generic disclosure and a long-term investor base. Not surprisingly, firms that practice more IR are more likely to issue a sustainability report, follow GRI guidelines, and have better EESG performance. Firms that issue a sustainability report, follow GRI guidelines, and have better EESG performance are larger. The rest of the variables exhibit economically important but more moderate correlations.

\section{Analysis and Results}

\subsection{Baseline Results}

Table 3 shows the results of estimating an ordinary least squares model with double clustered standard errors at the firm and year level to mitigate serial autocorrelation in the errors. The first specification includes industry and year fixed effects as well as accounting and stock market variables as controls. The coefficient on IR is positive and significant suggesting that firms practicing IR have a more long-term investor base. The coefficient is 0.035 with a t-statistic of 3.58. Approximately, the economic effect suggested by the estimates is about two percent shift in investor base (or about twenty percent of the LT Investor standard deviation) for an interquartile change in IR.

The specification includes controls for the quantity of sustainability disclosures. The estimated coefficient on this variable is insignificant suggesting that the number of sustainability metrics a firm discloses is not related to a firm's investor base. The specification also includes controls for whether the firm issues a separate sustainability report, whether the sustainability report follows the GRI guidelines, governance aspects of the organization, and the EESG performance score assigned to each firm by ASSET4 since all of them might be correlated omitted variables. The insignificant coefficient on the EESG performance score is likely an outcome of investors following both positive screening and engagement strategies. In positive screening strategies, investors choose companies with relatively better EESG 
performance with the expectation that better EESG performance will lead to better stock price performance in the future. In contrast, in engagement strategies, investors choose companies with relatively poor EESG performance with the expectation that after engaging with the company the improvement in EESG performance will lead to better stock price performance. Because investors follow both strategies there is no significant relation between EESG performance scores and investor base.

In the second specification, I include firm fixed effects to test whether potentially a firm-persistent correlated omitted variable causes IR and investor base to be related. However, I reject this hypothesis since the coefficient on IR remains positive and significant. The coefficient is 0.023 with a t-statistic of 3.03 . The explanatory power of the model increases from 21 to 57 percent suggesting that a firm's investor base is fairly stable in terms of long-term orientation. Moreover, while the coefficient on IR continues to be significant, the negative coefficient on Sustainability Reporting becomes insignificant. The same is true for the coefficient on Staggered Board. Approximately, the economic effect suggested by the estimates is about one percent shift in investor base (or about ten percent of the LT Investor standard deviation) for an interquartile change in IR.

To examine the robustness of these results to using an alternative measure of IR I use data from Sustainable Asset Management (SAM), a Swiss buy-side fund management company that constructs the Dow Jones Sustainability index and specializes in sustainable investing. SAM provided these proprietary data on a confidential basis and the data are not publicly available. SAM collected data for the first time in 2010 about the level of integration of environmental and social information in annual reports (Eccles and Serafeim, 2011). Specifically, analysts at SAM collected data on whether environmental or social narrative information or KPIs are integrated in annual reports. To construct an index of IR I give one point for whether a firm integrates environmental narrative information, social narrative information, environmental KPIs, or social KPIs. The index therefore ranges from zero to four. About 40 percent of the firms receive a score of zero and only five percent of the firms receive a score of four. Because SAM collects data on the largest 2,500 companies worldwide by market capitalization, the sample is reduced to 493 US firms. I estimate an ordinary least squares specification with these 493 observations for the year of 2010. The results in the third 
specification show that this alternative IR variable is positively associated with LT Investor. Approximately, the economic effect suggested by the estimates is about 2.5 percent shift in investor base (or about 25 percent of the LT Investor standard deviation) for an interquartile change in IR. I conclude that the results documented so far are robust to an alternative way of measuring the IR variable and using an alternative database. Therefore, the results are not specific to the ASSET4 database.

In terms of other control variables the estimated coefficients are consistent with the literature (Bushee 2001). Companies with higher stock market liquidity have relatively more transient investors as these investors need the liquidity in order to move in and out of the stock at a low cost. Moreover, firms with better past performance have relatively more transient investors reflecting the momentum strategies employed by such investors.

\subsection{Lead-Lag Analysis}

While the estimates in Table 3 suggest a robust relation between IR and investor clientele even in the presence of several control factors, the direction of causality is not clear. It might be that firms that practice IR signal their type and attract investors with similar preferences and time horizons. Or it might be the case that firms practice or not IR because of the preferences of their investor base. In other words, dedicated investors might force companies to practice IR or transient investors might discourage companies from practicing IR. To shed further light on the direction of causality I estimate lead-lag models where I calculate one-year and three-year difference in all variables and I lag either the changes in IR or the changes in LT Investor. I calculate both one and three-year changes because I am not certain how fast investors might react to the information or companies to investor pressure.

The first two specifications in Table 4 lag the change in IR and suggest that the lagged change in IR leads changes in LT Investor. In contrast the last two specifications reveal no relation between lag change in LT investor and future change in IR. IR leads investor base rather than the other way round. These results provide evidence in support of a mechanism where firms practice IR and attract investors that find this information most useful for their objectives. 


\subsection{Moderating Effects}

The results so far suggest that there is a robust positive association between IR and investor clientele. This association is likely to be moderated though by characteristics of the firm. First, I expect that incentives for the supply and demand of IR are stronger for firms with higher growth opportunities. Since the cash flows supporting the current market capitalization of these firms are forecasted to materialize further in the future, information about the long-term prospects of the business is more critical for these firms. I proxy for the growth opportunities of a firm using the price-to-book ratio.

Second, I expect the relation between IR and investor clientele to be weaker for family firms. A long literature argues that family firms have a more long-term orientation compared to other firms and they are more likely to better manage their relations with employees, customers and communities (Le BretonMiller and Miller 2006). Therefore, I expect that the signaling value of IR is lower for family firms. Twenty percent of the observations in my sample are family firms. I follow Anderson and Reeb (2003) and Villalonga and Amit (2007) and define a family firm as a firm whose founder or a member of the family either by blood or marriage is an officer, a director, or the owner of at least five percent of the firm's equity either individually or as a group.

Third, I expect that the strength of the relation between IR and investor clientele will increase with the magnitude and probability of future penalties and risks arising from changing regulations and changing social expectations that are likely to disrupt a firm's business model. I use a firm's presence in a 'sin' industry as a proxy for the severity and probability of future penalties. Firms involved in alcohol, firearms, tobacco, gambling, nuclear and military business as coded in the KLD database are classified as sin firms. Twelve percent of the observations are classified in sin industries.

Fourth, I expect that the relation between IR and investor clientele will be weaker for firms exhibiting very high past volatility in their IR practice. Commitment in disclosure has been shown to be necessary condition for credible disclosure (Leuz and Verrecchia 2000). These firms do not show a commitment in IR thereby decreasing the credibility of IR and its associated impact on investor clientele. I 
calculate the standard deviation of firm-specific IR over the past three years as an inverse measure of consistency and I designate the top ten percent of the distribution as High IR Volatility.

Table 5 presents the results of how these four variables moderate the relation between IR and investor clientele. The relation between IR and LT Investor is stronger for firms with higher price-to-book ratios (PTB) and sin firms. One standard deviation increase in PTB increases the economic effect of an interquartile change in IR from one percent to two percent shift in investor base. For a sin firm the economic effect increases from one percent to five percent shift in investor base. The relation is weaker for family firms and firms with high past IR volatility. For nonfamily firms an interquartile change in IR shifts the investor base towards long-term investors by almost two percent; by comparison the economic effect for the whole sample is one percent. The same is true for firms that do not exhibit high IR volatility. These results show that the relation between IR and investor clientele is predictably moderated by firm growth opportunities, ownership structure, the social legitimacy of the business, and disclosure commitment.

\subsection{Sustainability Events}

Past research attempts to identify what causes a firm to improve its environmental or social performance and increase transparency on those issues. I exploit findings from this line of research to understand how sustainability events lead to increases in IR and how this change in IR relates to future changes in investor base. Specifically, I consider the role of shareholder engagement with the company on environmental and social issues and how firms respond to sustainability-related crises.

\subsubsection{Shareholder Engagement}

While the results so far suggest that changes in IR lead to changes in investor base rather than vice versa, investor engagement on sustainability issues has been steadily increasing (DB Advisors 2009). An interesting question is whether such engagement is effective in influencing companies to practice IR and in turn whether such investor-led increases in IR lead to changes in investor base. I collect data on engagements by institutional investors on social and environmental issues from RiskMetrics to construct 
two variables. ${ }^{11}$ The first variable, Activism, takes the value of one if an investor has filed a proxy on a social and/or environmental issue for a company or otherwise it takes the value of zero. Eighteen percent of the firm-year observations in our sample have shareholder proposals on social and/or environmental issues (Table 1). The second variable, Reporting Activism, takes the value of one if the variable Activism is one and the investor demands that the company reports more information or it takes the value of zero otherwise. Five percent of the firm-year observations in our sample have reporting related social and/or environmental shareholder proposals. I expect that both variables will be related positively to changes in IR. The dataset includes proposals that came to a vote as well as those that did not (e.g., because they were withdrawn by the proponent or allowed to be omitted from the proxy by the SEC).

Table 6 shows that indeed investor engagement is positively associated with changes in IR. Both 1 and 3-year changes in IR are related to both activism and reporting activism. The result suggests that in general activism around environmental and/or social issues leads to an increase in the IR score of about 5 or 2 points over 3 or 1-year. Activism that relates also to reporting practices further increases IR by 6 or 4 points for a cumulative effect of 11 or 6 points. The third specification documents a similar effect in a levels specification with firm-fixed effects. Investor activism variables are constructed in this specification as indicator variables that take the value of one for the year on and after investor engagement to differentiate between years before and after the engagement. These are economically large estimates suggesting that activism has a large effect on IR.

Extracting the predicted component from the fixed effects specification allow us to test if this activism-led change in IR is associated with a change in investor base. The fourth specification shows that this incremental IR due to investor activism is related to higher levels of long-term investor holdings. The coefficient on predicted IR, from the first stage in the third specification, is significant and positive. This result is interesting in the light of recent evidence that investor engagements on environmental or social

\footnotetext{
${ }^{11}$ Not all investor engagements are public. Many investment funds engage privately with companies and I am unable to include those private engagements. If these private engagements are more effective at increasing IR then the estimated coefficient on the activism variables is likely to be biased towards zero and I will be unable to reject the null hypothesis.
} 
issues lead to operating improvements and superior stock price performance for the firm (Dimson, Karakas and Li 2013).

\subsubsection{Sustainability Crisis}

Past research has shown that major concerns about corporate conduct and the impact of a company on the environment or society have been the catalysts for firms to engage with sustainability (Eccles, Miller and Serafeim 2012). It is likely that such events could lead to more IR as firms attempt to explain how they are dealing with the problems and managing risks associated with future events. I collect data from KLD, a frequently used dataset that provides information on a firm's sustainability performance. KLD provides data on the number of concerns a firm faces regarding human rights, diversity, employee relations, product, governance and environmental issues. I calculate the sum of those concerns and I designated the top quintile of firms as facing a crisis. Firms that face a large number of concerns are more likely to receive negative media attention and pressure from civil society to address these concerns. Indicatively, the number of total concerns for the median firm in my sample is two. The firms I designated as facing a crisis have at least five concerns and up to 18 .

Table 7 shows that indeed the presence of a crisis is positively associated with changes in IR. Both 1 and 3-year changes in IR are related to the crisis variable. The result suggests that a crisis around environmental and/or social issues leads to an increase in the IR score of about 5 or 1 points over 3 or 1 year. The third specification documents a similar effect in a levels specification with firm-fixed effects. As before the indicator variable is transformed in this specification to take the value of one for years on and after the presence of a crisis. These are economically significant estimates suggesting that crisis has an effect on IR. Extracting the predicted component from the fixed effects specification allow us to test if this crisis-led change in IR is associated with a change in investor base. The fourth specification shows that this incremental IR due to the presence of a crisis is related to higher levels of long-term investor holdings. The coefficient on predicted IR, from the first stage in the third specification, is significant.

\subsection{Attracting Dedicated Investors or Discouraging Transient Investors}


So far I have documented a robust relation between IR and investor clientele. However, LT Investor comprises two variables: the percentage of shares held by dedicated investors minus the percentage of shares held by transient investors. It is not clear if the result is driven by just one of these variables or both. For example, is it the case that firms that practice IR signal their type only to dedicated investors attracting them or is it the case at the same time that they are unattractive to transient investors.

The results in Table 8 Panels A and B show that both effects exist although the effect on dedicated investors is the most robust. The coefficient on IR is positive and significant when the dependent variable is percentage of shares held by dedicated investors. In contrast, the coefficient on IR is negative and significant when the dependent variable is percentage of shares held by transient investors. The coefficient is negative but insignificant in the absence of firm fixed effects though. In the cross-section IR does not explain variation in the presence of transient investors. However, changes within a firm of IR do explain changes in transient ownership. Studies have shown that firms that exert more efforts to improve their environmental and social performance are less likely to engage in accruals and real earnings management (Kim, Park and Wier 2012), thereby potentially limiting the potential for transient investors to profit from momentum trading.

A few of the results are especially worth noting. First, firms that practice more IR but there is a high volatility in IR tend to attract more transient investors while they are unable to attract dedicated investors. These firms are not committed to IR thereby not attracting dedicated investors. Moreover, the volatility in IR attracts transient investors which are likely to benefit from volatile disclosure practices. Second, investor-induced IR has a positive effect on dedicated investor holdings but no effect on transient investors. This makes sense because dedicated investor are also the investors that filed the shareholder resolution that led to the increase in IR. Third, the crisis-induced IR has a negative effect on transient investor holdings but no effect on dedicated investors. Dedicated investors seem to be reluctant to increase holdings on companies that practice IR but have experienced a sustainability crisis.

\subsection{A Preliminary Analysis of Relevance, Reliability and Timeliness}


Section 2 hypothesizes that a relation between IR and investor base could be driven by IR increasing the relevance, reliability and timeliness of reported sustainability information. While a robust relation has been shown in the previous analyses, an open question is the relative importance of relevance, reliability and timeliness in driving this relation. Ideally, I would be able to construct variables measuring each one of these attributes and include them in the model to test which variables mediate the relation between IR and LT Investor. IR is capturing increased relevance due to integration but it is correlated with increased reliability and timeliness. To isolate, as much as possible, the effect of relevance I need to include variables for reliability and timeliness.

I proxy for reliability by hand-collecting data on whether the whole report is audited by an external party, if the auditor is a Big 4 firm, and whether the audit firm provides 'Reasonable' or 'Limited' assurance on the sustainability data. Given the size of the sample and because no readily available data exist on reliability and timeliness, I hand-collect data for a subsample. From the set of firms that issue sustainability reports and are included in the firm-fixed effects analysis I collect data on the first 100 companies ranked alphabetically (485 observations). I collect data alphabetically because I do not expect the first letter of a name of a company to be associated with any of my dependent or independent variables of interest. Ten percent of the sample has an external audit, and seven percent of the firms have a Big 4 audit firm. None of the audits provide Reasonable assurance. These low frequencies are not unexpected given that assurance of sustainability data is a relatively recent phenomenon (Simnett, Vanstraelen and Chua 2009). For this sample, I also hand-collect the reporting lag between financial year end and the date the report was issued to measure timeliness. The reporting lag is on average 172 days with a standard deviation of 36 days. The IR variable is positively correlated with both variables as expected. The correlation with external audit is 0.32, Big 4 auditor 0.39 and timeliness (defined as the natural logarithm of max reporting lag plus one minus reporting lag) 0.28 .

I estimate the relations as in Table 3 with all the control variables and industry fixed effects (the fourth specification). In Table 9 I find that the coefficient on IR is still positive and significant $(\mathrm{t}=2.67)$ suggesting that when I control for reliability and timeliness, increased relevance due to increased integration 
is correlated with a more long-term investor base. I use the two audit variables in separate models as they are highly correlated but the estimated coefficients on the reliability variables are insignificant (Table 9 tabulates the specification with the external audit variable). In this sample, it does not seem that increased reliability due to audit is correlated with a more long-term investor base. Readers should interpret these findings with caution for two reasons. First, this does not mean that increased reliability in IR can be the source of the relation between the IR variable and LT investor. External auditing is just one source of increased reliability. Other sources include improved information and management control systems inside the firm due to the practice of IR and I am unable to proxy for these. Second, as it was mentioned before auditing of sustainability data is a relatively recent phenomenon. It could be that auditing could be significantly correlated in the future as more investors become familiar with the audit practices in this new domain. The timeliness variable loads with a positive and significant coefficient $(t=1.98)$ suggesting that timeliness of sustainability data is correlated with a long-term investor base. When I estimate for this sample the same model but using firm instead of industry fixed effects (Table 3 column 5) the coefficient on the IR variable remains positive but now it is marginally significant $(\mathrm{t}=1.90)$ and both the reliability and timeliness variables are positive but insignificant. However, these results using firm fixed effects should be interpreted with caution given the low power of the test due to the decreased sample.

\section{Conclusion}

IR is a recent reporting innovation that has gained traction across both the corporate and investor community. In this paper, I examine how the practice of IR affects the investor base of the firm. I find that firms that practice more IR have a more long-term investor base and that this result is driven by having more dedicated and fewer transient investors. Using firm-fixed effects and lead-lag analysis I find evidence supporting a causal mechanism from IR to the investor base of a firm. The relation between IR and investor base is stronger for firms with high growth opportunities, nonfamily firms, sin firms, and firms with not very high volatility in past IR practice. Moreover, I find that investor activism on sustainability issues and 
the presence of a sustainability crisis leads firms to practice more IR and this change in IR is related to changes in investor base.

While the results I document appear robust to different specifications and variables used, my tests are not designed to address the question of which elements of IR are most effective at attracting long-term investors. As the content of IR becomes more standardized researchers will be able to create content classification and investigate their differential impact. I leave this important question for future research. Moreover, the paper does not provide any evidence that the information reported in IR allows long-term investors to make better decisions. While I document a matching between firms practicing IR and longterm investors, there is an open question about how these investors change capital allocation decisions based on the information in IR.

It is important to note that IR is a costly activity and we are still not able to establish whether the benefits exceed the costs. So even if a company views attraction of long-term investors as a benefit, the costs should not be ignored. Anecdotal evidence and field data suggest that the most important costs involve investments in improving information systems for sustainability data, acquiring skills and expertise to use the data and integrate them in financial reporting, and increasing cross-functional collaboration inside the organization to produce an integrated report. Proprietary costs from the disclosure of competitive information might also be added to the costs of IR, although no evidence exists to date suggesting that IR increases the proprietary costs of disclosure.

IR is a rare experiment in fundamentally changing corporate reporting that represents a rich area for future research. We still know relatively little about its causes and consequences. More research is needed on what are the motivations of different firms that practice IR. Similarly, more research could shed light on whether and how IR instills 'integrated thinking' inside the firm. While IR should reflect the integrated thinking inside a firm it could also serve as the discipline for managers to change resource allocation decisions inside the organization. 


\section{References}

Accounting for Sustainability and the Global Reporting Initiative. 2012. "The Value of Extra-financial Disclosure: What Investors and Analysts Said."

Anderson, Roland, and David Reeb. 2003. "Founding Family Ownership and Firm Performance: Evidence from the S\&P 500.” Journal of Finance 58, no. 3: 1301-1329.

Barton, Dominick, and Mark Wiseman. 2014. "Focusing Capital on the Long-term." Harvard Business Review, January-February.

Basu, Sudipta. 1997. "The Conservatism Principle and the Asymmetric Timeliness of Earnings." Journal of Accounting and Economics 24, no. 1: 3-37.

Bolton, Patrick, Jose Scheinkman, and Wei Xiong. 2006. "Executive compensation and short-termist behavior in speculative markets." Review of Economic Studies 73, no. 3: 577-610.

Brochet, Francois, Maria Loumioti, and George Serafeim. 2013. "Short-Termism, Investor Clientele, and Firm Performance." Harvard Business School Working Paper, No. 12-072.

Bushee, Brian. 1998. "The Influence of Institutional Investors on Myopic R\&D Investment Behavior." Accounting Review, 73 no. 3: 19 - 45.

Bushee, Brian, and Christopher Noe. 2000. "Corporate Disclosure Practices, Institutional Investors, and Stock Return Volatility.” Journal of Accounting Research, 38: 171-202.

Bushee, Brian. 2001. "Do Institutional Investors Prefer Near-Term Earnings over Long-Run Value?" Contemporary Accounting Research 18, no. 2: 207-246.

Bushee, Brian, Mary Ellen Carter and Joseph Gerakos. 2009. "Institutional Investor Preferences for Corporate Governance Mechanisms.” Available at SSRN: http://ssrn.com/abstract=1070168

Chen, Xia, Jarrad Harford, and Kai Li. 2007. "Monitoring: Which Institutions Matter?" Journal of Financial Economics 86, no. 2: 279-305.

Cheng, Beiting, Ioannis Ioannou, and George Serafeim. 2013. "Corporate Social Responsibility and Access to Finance." Strategic Management Journal 35, no. 1: 1-23.

Collins, Daniel, SP Kothari, Jay Shanken, and Richard Sloan. 1994. "Lack of Timeliness versus Noise as Explanations for Low Contemporaneous Return-Earnings Association." Journal of Accounting and Economics 18 no. 3: 289-324.

Deutsche Bank Advisors. 2009. “Corporate Engagement by Institutional Shareholders.” Deutche Bank Group.

Dhaliwal, Dan, Oliver Zhen Li, Albert Tsang, and Yong George Yang. 2011. "Voluntary Nonfinancial Disclosure and the Cost of Equity Capital: The Initiation of Corporate Social Responsibility Reporting." The Accounting Review 86 no. 1: 59-100. 
Dhaliwal, Dan, Suresh Radhakrishnan, Albert Tsang, and Yong George Yang. 2012. "Nonfinancial Disclosure and Analyst Forecast Accuracy: International Evidence on Corporate Social Responsibility Disclosure." The Accounting Review 87 no. 3: 723-759.

Dimson, Elroy, Oğuzhan Karaka and Xi Li. 2013. “Active Ownership.” Working Paper.

Eccles, Robert. 1991. "The Performance Measurement Manifesto." The Harvard Business Review 69 no. 1: 131-137.

Eccles, Robert, Robert Herz, Mary Keegan, and David Phillips. 2001. The Value Reporting Revolution: Moving Beyond the Earnings Game. New York: John Wiley \& Sons, Inc.

Eccles, Robert, and Michael Krzus. 2010. One Report: Integrated Reporting for a Sustainable Strategy. New York: John Wiley and Sons, Inc.

Eccles, Robert, Michael Krzus, and George Serafeim. 2011. "Market Interest in Nonfinancial Information." Journal of Applied Corporate Finance 23, no. 4: 113-127.

Eccles, Robert, and George Serafeim. 2011. "The Role of the Board in Accelerating the Adoption of Integrated Reporting." Director Notes (The Conference Board).

Eccles, Robert, Ioannis Ioannou, and George Serafeim. 2014. "The Impact of Corporate Sustainability on Organizational Processes and Performance." Management Science, forthcoming.

Eurosif and ACCA. 2013. "What do Investors Expect from Non-financial Reporting?"

Gaspar, Jose-Miguel, Massimo Matta, and Pedro Matos. 2005. "Shareholder Investment Horizons and the Market for Corporate Control." Journal of Financial Economics 76: 135-165.

Givoly, Dan and Dan Palmon. 1982. "Timeliness of Annual Earnings Announcements: Some Empirical Evidence." The Accounting Review 57, no. 3: 486-508.

Griffin, Paul A. and Yuan Sun. 2013. "Going Green: Market Reaction to CSR Newswire Releases." UC Davis Working Paper.

Healy, Paul, and Krishna Palepu, 2001. "Information Asymmetry, Corporate Disclosure, and the Capital Markets: A Review of the Empirical Disclosure Literature." Journal of Accounting \& Economics 31: 405440.

Hubbard, Glenn. 1998. "Capital-Market Imperfections and Investment." Journal of Economic Literature 36: $193-225$.

Hung, Mingyi, Jing Shi, and Yongxiang Wang. 2013. "The Effect of Mandatory CSR Disclosure on Information Asymmetry: Evidence from a Quasi-natural Experiment in China." Working paper.

Investor Responsibility Research Center (IRRC) and Sustainable Investments Institute (SII). 2013. Integrated Financial and Sustainability Reporting in the United States.

Ioannou, Ioannis, and George Serafeim. 2012. "What Drives Corporate Social Performance? The Role of Nation-level Institutions." Journal of International Business Studies 43, no. 9: 834-864. 
Ioannou, Ioannis, and George Serafeim. 2013. "The Consequences of Mandatory Corporate Sustainability Reporting.” Harvard Business School Working Paper, No. 11-100.

Ioannou, Ioannis and George Serafeim. 2014. "The Impact of Corporate Social Responsibility on Investment Recommendations." Harvard Business School Working Paper No. 1507874.

Kallapur, Sanjay and Sabrina Y. S. Kwan. 2004. "The Value Relevance and Reliability of Brand Assets Recognized by U.K. Firms.” The Accounting Review 79, no. 1: 151-172.

Kim, Yongtae, Myung Seok Park, and Benson Wier. 2012. "Is Earnings Quality Associated with Corporate Social Responsibility?" The Accounting Review 87, no. 3: 761-796.

Le Breton-Miller, Isabelle and Danny Miller. 2006. "Why Do Some Family Businesses Out-Compete? Governance, Long-Term Orientations, and Sustainable Capability." Entrepreneurship Theory and Practice 30, no. 6: 731-746.

Leuz, Christian, and Robert Verrecchia. 2000. "The Economic Consequences of Increased Disclosure." Journal of Accounting Research 38, supplement: 91-124.

Matsumoto, Dawn. 2002. "Management's Incentives to Avoid Negative Earnings Surprises." The Accounting Review 77, no. 3: 483-514.

Merton, Robert C. 1987. "A Simple Model of Capital Market Equilibrium with Incomplete Information." Journal of Finance 42: 483-509.

Simnett, Roger, Ann Vastraelen, and Wai Fong Chua. 2009. “Assurance on Sustainability Reports: An International Comparison." The Accounting Review 84, no. 3: 937-967.

Villalonga, Belen, and Raphael Amit. 2007. "How do Family Ownership, Control and Management Affect Firm Value?" Journal of Financial Economics 80: 385-417.

Yu. Kun, Shuili Du, and C.B. Bhattacharya. 2014. "Everybody's Talking But is Anybody Listening? Stock Market Reactions to Corporate Social Responsibility Communications." Working paper.

Zahra, Shaker, Donald Neubaum and Morten Huse. 2000. "Entrepreneurship in Medium-size Companies: Exploring the Effects of Ownership and Governance Systems." Journal of Management 26, no. 5: 947-976. 


\section{Appendix: Description of Variables}

\begin{tabular}{|c|c|}
\hline Variables & Description \\
\hline LT Investor & $\%$ of shares held by dedicated minus transient investors \\
\hline Dedicated & $\%$ of shares held by dedicated investors \\
\hline Transient & $\%$ of shares held by transient investors \\
\hline Institutional & $\%$ of shares held by dedicated, transient and quasi-index investors \\
\hline IR & $\begin{array}{l}\text { Measures a company's management commitment and effectiveness towards the creation of an } \\
\text { overarching vision and strategy integrating financial and extra-financial aspects. It reflects a } \\
\text { company's capacity to convincingly show and communicate that it integrates the economic, social } \\
\text { and environmental dimensions into its day-to-day decision-making processes }\end{array}$ \\
\hline Disclosure Quantity & $\%$ of quantitative ESG metrics that a firm disclosed for a fiscal year \\
\hline Sustainability Report & Does the company publish a separate $\mathrm{CSR} / \mathrm{H} \& \mathrm{~S} / \mathrm{Sustainability} \mathrm{report?}$ \\
\hline GRI & Is the company's CSR report published in accordance with the GRI guidelines? \\
\hline Classified Board & Does the company have a classified board structure? \\
\hline Staggered Board & Does the company have a staggered board structure? \\
\hline Supermajority Vote & $\begin{array}{l}\text { Does the company have a supermajority vote requirement or qualified majority (for amendments } \\
\text { of charters and bylaws or lock-in provisions)? }\end{array}$ \\
\hline EESG Score & $\begin{array}{l}\text { An equal-weighted rating of a company's financial and extra-financial health based on the } \\
\text { information in ASSET4's economic, environmental, social and corporate governance pillars. It } \\
\text { reflects a balanced view of a company's performance in these four areas. }\end{array}$ \\
\hline Firm Size & Natural logarithm of firm sales \\
\hline Leverage & Total debt over total assets \\
\hline $\mathrm{E} / \mathrm{P}$ & EPS over stock price at fiscal year end \\
\hline PTB & Stock price over book value per-share \\
\hline Dividend Yield & Dividends over stock price at fiscal year end \\
\hline Sales Growth & One year rate of change in sales \\
\hline Beta & Equity beta estimated using CAPM for monthly data over five years \\
\hline Volatility & Stock return volatility over the fiscal year \\
\hline Turnover & Dollar volume of trading over the year as a percentage of market value of equity at fiscal year end \\
\hline Stock Return & Stock return over the fiscal year \\
\hline Family Firm & Indicator variable that takes the value of one if the firm is controlled by a family \\
\hline Sin Firm & $\begin{array}{l}\text { Indicator variable that takes the value of one if the firm is involved in gambling, tobacco, alcohol, } \\
\text { firearms, nuclear or military business }\end{array}$ \\
\hline Sustainability Engagement & $\begin{array}{l}\text { Indicator variable that takes the value of one if a firm has had a shareholder resolution on } \\
\text { environmental and/or social issues in that year }\end{array}$ \\
\hline Sustainability Reporting Engagement & $\begin{array}{l}\text { Indicator variable that takes the value of one if a firm has had a shareholder resolution on } \\
\text { environmental and/or social issues that relates to reporting of data in that year }\end{array}$ \\
\hline Sustainability Engagement After & $\begin{array}{l}\text { Indicator variable that takes the value of one for all years after a firm has had a shareholder } \\
\text { resolution on environmental and/or social issues }\end{array}$ \\
\hline Sustainability Reporting Engagement After & $\begin{array}{l}\text { Indicator variable that takes the value of one for all years after a firm has had a shareholder } \\
\text { resolution on environmental and/or social issues that relates to reporting of data }\end{array}$ \\
\hline Sustainability Crisis & $\begin{array}{l}\text { Indicator variable that takes the value of one if a firm ranks in the top } 20 \% \text { of number of human } \\
\text { rights, employee related, environmental, product, and diversity concerns in the KLD dataset }\end{array}$ \\
\hline Sustainability Crisis After & $\begin{array}{l}\text { Indicator variable that takes the value of one for years after a firm ranks in the top } 20 \% \text { of number } \\
\text { of human rights, employee related, environmental, product, and diversity concerns in the KLD } \\
\text { dataset }\end{array}$ \\
\hline
\end{tabular}


Table 1: Summary Statistics

\begin{tabular}{|c|c|c|c|c|c|}
\hline Variable & $\mathrm{N}$ & Mean & $\mathrm{Q} 1$ & Q3 & St Dev \\
\hline \multicolumn{6}{|l|}{ Investor Ownership Data } \\
\hline LT Investor & 5,726 & -6.06 & -12.02 & -0.24 & 10.64 \\
\hline Dedicated & 5,726 & 9.42 & 4.09 & 13.21 & 7.60 \\
\hline Transient & 5,726 & 15.48 & 9.47 & 20.42 & 8.09 \\
\hline Quasi-index & 5,726 & 46.83 & 39.99 & 56.08 & 13.81 \\
\hline Institutional & 5,726 & 71.73 & 61.75 & 85.89 & 18.93 \\
\hline \multicolumn{6}{|l|}{ Reporting Data } \\
\hline IR & 5,726 & 39.09 & 18.13 & 61.78 & 28.99 \\
\hline Disclosure Quantity & 5,726 & 54.17 & 50.41 & 57.85 & 6.19 \\
\hline Sustainability Report & 5,726 & 0.21 & 0.00 & 0.00 & 0.41 \\
\hline GRI & 5,726 & 0.13 & 0.00 & 0.00 & 0.34 \\
\hline \multicolumn{6}{|l|}{ Governance Data } \\
\hline Classified Board & 5,726 & 0.07 & 0.00 & 0.00 & 0.26 \\
\hline Staggered Board & 5,726 & 0.45 & 0.00 & 1.00 & 0.50 \\
\hline Supermajority Vote & 5,726 & 0.32 & 0.00 & 1.00 & 0.47 \\
\hline \multicolumn{6}{|l|}{ Firm Characteristics } \\
\hline EESG Score & 5,726 & 53.57 & 28.09 & 82.10 & 28.48 \\
\hline Firm Size & 5,726 & 8.45 & 7.55 & 9.34 & 1.37 \\
\hline Leverage & 5,726 & 24.13 & 9.67 & 34.99 & 18.51 \\
\hline $\mathrm{E} / \mathrm{P}$ & 5,726 & 3.55 & 2.84 & 6.96 & 9.75 \\
\hline РТВ & 5,726 & 3.31 & 1.56 & 3.94 & 3.07 \\
\hline Dividend Yield & 5,726 & 1.64 & 0.00 & 2.50 & 1.94 \\
\hline Sales Growth & 5,726 & 9.33 & -0.70 & 16.48 & 21.98 \\
\hline Beta & 5,726 & 1.17 & 0.82 & 1.50 & 0.57 \\
\hline Volatility & 5,726 & 28.44 & 21.41 & 32.72 & 9.43 \\
\hline Turnover & 5,726 & 271.22 & 123.24 & 318.07 & 263.17 \\
\hline Stock Return & 5,726 & 16.25 & -9.49 & 34.25 & 48.62 \\
\hline Family Firm & 5,726 & 0.20 & 0.00 & 0.00 & 0.40 \\
\hline Sin Firm & 5,726 & 0.12 & 0.00 & 0.00 & 0.33 \\
\hline \multicolumn{6}{|l|}{ Shareholder Activism Data } \\
\hline Sustainability Engagement & 5,726 & 0.18 & 0.00 & 0.00 & 0.38 \\
\hline Sustainability Reporting Engagement & 5,726 & 0.05 & 0.00 & 0.00 & 0.21 \\
\hline Sustainability Engagement After & 5,726 & 0.29 & 0.00 & 1.00 & 0.45 \\
\hline Sustainability Reporting Engagement After & 5,726 & 0.12 & 0.00 & 0.00 & 0.32 \\
\hline \multicolumn{6}{|l|}{ Sustainability Crisis Data } \\
\hline Sustainability Crisis & 5,726 & 0.21 & 0.00 & 0.00 & 0.41 \\
\hline Sustainability Crisis After & 5,726 & 0.26 & 0.00 & 1.00 & 0.44 \\
\hline
\end{tabular}

All variables are defined in the Appendix. 
Table 2: Correlation Matrix

\begin{tabular}{|c|c|c|c|c|c|c|c|c|c|c|c|c|c|c|c|c|c|c|c|}
\hline & Variable & 1 & 2 & 3 & 4 & 5 & 6 & 7 & 8 & 9 & 10 & 11 & 12 & 13 & 14 & 15 & 16 & 17 & 18 \\
\hline 1 & LT Investor & 1.000 & & & & & & & & & & & & & & & & & \\
\hline 2 & IR & 0.091 & 1.000 & & & & & & & & & & & & & & & & \\
\hline 3 & Disclosure Quantity & -0.030 & 0.524 & 1.000 & & & & & & & & & & & & & & & \\
\hline 4 & Sustainability Report & -0.047 & 0.619 & 0.460 & 1.000 & & & & & & & & & & & & & & \\
\hline 5 & GRI & -0.013 & 0.587 & 0.460 & 0.651 & 1.000 & & & & & & & & & & & & & \\
\hline 6 & EESG Performance & 0.074 & 0.595 & 0.576 & 0.530 & 0.488 & 1.000 & & & & & & & & & & & & \\
\hline 7 & Classified Board & 0.043 & -0.038 & -0.048 & -0.127 & -0.092 & -0.029 & 1.000 & & & & & & & & & & & \\
\hline 8 & Staggered Board & -0.091 & -0.138 & -0.054 & -0.098 & -0.123 & -0.097 & 0.243 & 1.000 & & & & & & & & & & \\
\hline 9 & Supermajority Vote & -0.106 & -0.012 & 0.022 & 0.115 & 0.063 & 0.024 & -0.105 & 0.214 & 1.000 & & & & & & & & & \\
\hline 10 & Firm Size & 0.139 & 0.433 & 0.315 & 0.301 & 0.249 & 0.530 & 0.036 & -0.073 & -0.047 & 1.000 & & & & & & & & \\
\hline 11 & Leverage & 0.075 & 0.012 & -0.012 & 0.014 & -0.005 & -0.086 & 0.000 & -0.004 & -0.013 & 0.024 & 1.000 & & & & & & & \\
\hline 12 & $\mathrm{E} / \mathrm{P}$ & -0.003 & 0.085 & 0.080 & 0.055 & 0.043 & 0.170 & -0.013 & 0.017 & -0.015 & 0.157 & -0.102 & 1.000 & & & & & & \\
\hline 13 & РTB & 0.037 & 0.004 & 0.122 & -0.056 & 0.003 & 0.033 & 0.018 & -0.037 & -0.059 & -0.080 & -0.022 & 0.032 & 1.000 & & & & & \\
\hline 14 & Dividend Yield & 0.075 & 0.136 & -0.091 & 0.117 & 0.089 & 0.093 & -0.017 & -0.004 & 0.019 & 0.120 & 0.269 & 0.047 & -0.157 & 1.000 & & & & \\
\hline 15 & Sales Growth & -0.071 & -0.050 & -0.012 & -0.084 & -0.052 & -0.018 & -0.003 & -0.008 & -0.085 & -0.050 & -0.085 & 0.139 & 0.153 & -0.149 & 1.000 & & & \\
\hline 16 & Beta & -0.100 & -0.101 & -0.051 & -0.044 & -0.080 & -0.111 & 0.002 & 0.060 & 0.048 & -0.105 & -0.015 & -0.160 & -0.092 & -0.194 & 0.031 & 1.000 & & \\
\hline 17 & Volatility & -0.222 & -0.211 & -0.049 & -0.113 & -0.105 & -0.247 & -0.009 & 0.005 & 0.082 & -0.314 & -0.117 & -0.271 & 0.017 & -0.417 & 0.079 & 0.404 & 1.000 & \\
\hline 18 & Turnover & -0.251 & -0.122 & 0.021 & -0.012 & -0.026 & -0.113 & -0.061 & 0.018 & 0.123 & -0.104 & 0.006 & -0.270 & -0.097 & -0.026 & 0.009 & 0.282 & 0.451 & 1.000 \\
\hline 19 & Stock Return & -0.054 & -0.023 & 0.027 & -0.018 & -0.002 & -0.025 & -0.014 & 0.008 & 0.066 & -0.117 & -0.036 & 0.073 & 0.182 & -0.233 & 0.044 & 0.114 & 0.219 & -0.250 \\
\hline
\end{tabular}

Pearson correlation statistics. All variables are defined in the Appendix. 


\section{Table 3: IR and Investor Clientele}

\begin{tabular}{|c|c|c|c|c|c|c|}
\hline Parameter & Estimate & $\mathrm{t}$ & Estimate & $\mathrm{t}$ & Estimate & $\mathrm{t}$ \\
\hline Intercept & -13.269 & -3.20 & -3.783 & -0.38 & -0.130 & -0.02 \\
\hline IR & $\mathbf{0 . 0 3 5}$ & 3.58 & $\mathbf{0 . 0 2 3}$ & $\mathbf{3 . 0 3}$ & 0.669 & 2.03 \\
\hline Disclosure Quantity & -0.012 & -0.19 & -0.027 & -0.54 & 0.099 & 0.47 \\
\hline Sustainability Report & -2.099 & -2.84 & -0.832 & -1.00 & -0.009 & -0.40 \\
\hline GRI & -0.498 & -0.94 & -0.791 & -1.44 & 0.009 & 0.47 \\
\hline EESG Performance & 0.005 & 0.44 & -0.016 & -0.99 & 0.510 & 0.15 \\
\hline Classified Board & 0.116 & 0.18 & -0.068 & -0.16 & -1.649 & -1.46 \\
\hline Staggered Board & -1.378 & -3.16 & 0.362 & 0.83 & 1.009 & 1.01 \\
\hline Supermajority Vote & 0.615 & 1.57 & 0.201 & 0.66 & 0.045 & 0.62 \\
\hline Firm Size & 0.538 & 2.64 & 0.574 & 1.29 & 0.536 & 1.12 \\
\hline Leverage & 0.040 & 2.61 & 0.008 & 0.46 & 0.040 & 1.41 \\
\hline $\mathrm{E} / \mathrm{P}$ & -0.069 & -3.96 & -0.066 & -4.22 & -0.057 & -1.52 \\
\hline PTB & 0.062 & 0.95 & -0.105 & -1.69 & 0.006 & 0.11 \\
\hline Dividend Yield & -0.021 & -0.15 & -0.091 & -0.84 & -0.210 & -0.69 \\
\hline Sales Growth & -0.031 & -4.77 & -0.021 & -2.98 & -0.054 & -1.99 \\
\hline Beta & -0.264 & -0.45 & 1.974 & 0.31 & -1.028 & -1.08 \\
\hline Volatility & -0.077 & -2.09 & -0.156 & -3.83 & -0.088 & -1.97 \\
\hline Turnover & -0.008 & -8.03 & -0.002 & -2.31 & -0.007 & -3.27 \\
\hline Stock Return & -0.016 & -4.37 & -0.010 & -2.67 & -0.018 & -2.55 \\
\hline Year f.e. & Yes & & Yes & & No & \\
\hline Industry f.e. & Yes & & No & & Yes & \\
\hline Firm f.e. & No & & Yes & & No & \\
\hline Adj R-squared & $21.4 \%$ & & $57.0 \%$ & & $13.8 \%$ & \\
\hline $\mathrm{N}$ & 5,726 & & 4,684 & & 493 & \\
\hline
\end{tabular}

OLS regressions with robust and clustered standard errors at the firm and year level. The dependent variable is LT Investor which is calculated as the difference between percentage of shares owned by dedicated and transient investors for a given firm and year. All variables are defined in the Appendix. IR is defined as in the appendix except for IR in the third specification which is a measure of IR that ranges from 0 to 4 with higher values representing more integration of environmental and social information in financial reporting. 
Table 4: Lead-lag Analysis

\begin{tabular}{lrrrrrrrr}
\hline & \multicolumn{3}{c}{ Differences lagged IR } & \multicolumn{4}{c}{ Differences lagged LT Investor } \\
\hline Parameter & 3-year & \multicolumn{4}{c}{ 1-year } & \multicolumn{1}{c}{ 3-year } & 1-year \\
\hline Intercept & Estimate & \multicolumn{1}{c}{$\mathrm{t}$} & Estimate & \multicolumn{1}{c}{$\mathrm{t}$} & Estimate & \multicolumn{1}{c}{ t } & Estimate & \multicolumn{1}{c}{$\mathrm{t}$} \\
IR & -3.038 & -9.17 & -1.625 & -14.57 & -1.311 & -3.75 & -0.597 & -5.18 \\
Disclosure & $\mathbf{0 . 0 2 2}$ & $\mathbf{1 . 9 6}$ & $\mathbf{0 . 0 1 3}$ & $\mathbf{1 . 6 1}$ & $\mathbf{0 . 0 1 0}$ & $\mathbf{0 . 8 5}$ & $\mathbf{0 . 0 0 2}$ & $\mathbf{0 . 2 9}$ \\
Sustainability Report & 0.115 & 1.57 & -0.045 & -0.82 & 0.147 & 1.93 & 0.092 & 1.64 \\
GRI & -0.022 & -1.29 & -0.003 & -0.42 & -0.020 & -1.03 & -0.004 & -0.62 \\
Classified Board & -0.016 & -1.05 & -0.001 & -0.14 & -0.009 & -0.99 & -0.006 & -0.96 \\
Staggered Board & -0.018 & -1.59 & -0.004 & -0.37 & -0.010 & -0.82 & -0.010 & -1.09 \\
Supermajority Vote & -0.619 & -0.92 & -0.900 & -2.67 & -0.195 & -0.28 & 0.208 & 0.64 \\
EESG Score & 0.384 & 0.60 & 0.863 & 1.46 & 0.354 & 0.50 & 0.364 & 0.59 \\
Firm Size & -0.198 & -0.42 & 0.252 & 0.82 & -0.448 & -0.88 & 0.140 & 0.42 \\
Leverage & 1.160 & 1.45 & 1.990 & 2.83 & -0.008 & -0.01 & 0.074 & 0.10 \\
E/P & -0.006 & -0.26 & 0.041 & 2.10 & 0.030 & 1.28 & -0.008 & -0.43 \\
PTB & -0.113 & -4.20 & -0.027 & -2.22 & -0.065 & -2.76 & -0.012 & -0.90 \\
Dividend Yield & -0.129 & -1.28 & -0.035 & -0.64 & -0.176 & -1.50 & -0.058 & -0.98 \\
Sales Growth & -0.173 & -1.20 & -0.230 & -2.30 & -0.056 & -0.32 & 0.270 & 2.81 \\
Volatility & -0.016 & -2.12 & -0.031 & -4.86 & 0.003 & 0.44 & 0.018 & 3.25 \\
Turnover & -0.268 & -4.76 & -0.118 & -2.28 & -0.225 & -3.93 & -0.150 & -3.09 \\
Stock Return & -0.001 & -1.25 & 0.000 & 0.27 & -0.001 & -0.75 & 0.001 & 1.35 \\
Adj R-squared & -0.002 & -0.54 & 0.010 & 5.74 & 0.004 & 0.79 & 0.003 & 1.32 \\
N & $2.2 \%$ & & $1.7 \%$ & & $1.9 \%$ & & $0.0 \%$ & \\
\hline & 2,791 & & 2,913 & & 2,791 & & 2,913 & \\
\hline
\end{tabular}

OLS regressions with robust and clustered standard errors at the firm and year level. The dependent variable is change in LT Investor which is calculated as the difference between percentage of shares owned by dedicated and transient investors for a given firm and year. All independent variables are calculated as changes. The first and third specifications calculate changes for all variables over 3-years. The second and fourth specifications calculate changes for all variables over 1year. In the first two specifications change in IR is calculated for year t-1 while change in LT Investor is calculated in year t. In the last two specifications change in IR is calculated for year t while change in LT Investor is calculated in year t-1. 


\section{Table 5: IR and Investor Clientele: Moderating Effects}

\begin{tabular}{|c|c|c|c|c|c|c|c|c|c|c|}
\hline Parameter & Estimate & $\mathrm{t}$ & Estimate & $\mathrm{t}$ & Estimate & $\mathrm{t}$ & Estimate & $\mathrm{t}$ & Estimate & $\mathrm{t}$ \\
\hline Intercept & -13.025 & -3.15 & -12.989 & -3.12 & -13.613 & -3.35 & -12.762 & -3.11 & -12.591 & -3.14 \\
\hline IR & 0.026 & 2.23 & 0.042 & 4.24 & 0.027 & 2.66 & 0.043 & 4.11 & $\mathbf{0 . 0 3 3}$ & 2.65 \\
\hline IR* PTB & 0.003 & 1.88 & & & & & & & 0.003 & 1.68 \\
\hline IR* Family Firm & & & -0.033 & -2.08 & & & & & -0.033 & -2.04 \\
\hline IR* Sin Firm & & & & & 0.042 & 2.87 & & & 0.041 & 2.82 \\
\hline IR* High IR Volatility & & & & & & & -0.057 & -2.81 & -0.059 & -2.78 \\
\hline PTB & -0.023 & -0.24 & & & & & & & -0.033 & -0.36 \\
\hline Family Firm & & & 1.937 & 1.99 & & & & & 1.927 & 1.97 \\
\hline Sin Firm & & & & & -3.385 & -3.20 & & & -3.344 & -3.16 \\
\hline High IR Volatility & & & & & & & 3.470 & 2.27 & 3.669 & 2.30 \\
\hline Firm Controls & Yes & & Yes & & Yes & & Yes & & Yes & \\
\hline Year f.e. & Yes & & Yes & & Yes & & Yes & & Yes & \\
\hline Industry f.e. & Yes & & Yes & & Yes & & Yes & & Yes & \\
\hline Adj R-squared & $20.7 \%$ & & $20.7 \%$ & & $21.0 \%$ & & $21.0 \%$ & & $21.4 \%$ & \\
\hline $\mathrm{N}$ & 5,726 & & 5,726 & & 5,726 & & 5,726 & & 5,726 & \\
\hline
\end{tabular}

OLS regressions with robust and clustered standard errors at the firm and year level. The dependent variable is LT Investor which is calculated as the difference between percentage of shares owned by dedicated and transient investors for a given firm and year. All variables are defined in the Appendix. 


\section{Table 6: Investor Engagement, IR and Investor Clientele}

\begin{tabular}{|c|c|c|c|c|c|c|c|c|}
\hline Dependent Variable & 3-year IR c & lange & 1-year IR & lange & IR & & LT Inve & \\
\hline Parameter & Estimate & $\mathrm{t}$ & Estimate & $\mathrm{t}$ & Estimate & $\mathrm{t}$ & Estimate & $\mathrm{t}$ \\
\hline Intercept & 5.582 & 7.43 & 1.563 & 7.20 & 38.865 & 0.87 & -9.024 & -0.91 \\
\hline Sustainability Engagement & 3.679 & 2.89 & 1.095 & 1.83 & & & & \\
\hline Sustainability Reporting Engagement & 6.064 & 2.73 & 3.276 & 2.42 & & & & \\
\hline Sustainability Engagement After & & & & & $\mathbf{3 . 5 5 7}$ & 3.34 & & \\
\hline Sustainability Reporting Engagement After & & & & & 6.858 & 5.20 & & \\
\hline Predicted IR & & & & & & & 0.140 & 2.76 \\
\hline Disclosure Quantity & & & & & & & -0.028 & -0.56 \\
\hline Sustainability Report & & & & & & & -0.328 & -0.86 \\
\hline GRI & & & & & & & -0.591 & -1.45 \\
\hline EESG Performance & & & & & & & -0.008 & -1.11 \\
\hline Classified Board & & & & & & & -0.056 & -0.13 \\
\hline Staggered Board & & & & & & & 0.430 & 0.99 \\
\hline Supermajority Vote & & & & & & & 0.221 & 0.73 \\
\hline Firm Size & -0.307 & -0.21 & 0.293 & 0.43 & 0.790 & 0.59 & 0.521 & 1.15 \\
\hline Leverage & -0.005 & -0.17 & -0.022 & -0.92 & -0.034 & -1.05 & 0.013 & 0.76 \\
\hline $\mathrm{E} / \mathrm{P}$ & 0.063 & 1.62 & -0.016 & -0.73 & 0.066 & 1.95 & -0.077 & -4.76 \\
\hline PTB & -0.181 & -0.91 & -0.071 & -0.73 & 0.179 & 1.32 & -0.130 & -2.10 \\
\hline Dividend Yield & 0.468 & 1.41 & 0.329 & 2.02 & 0.229 & 0.84 & -0.121 & -1.12 \\
\hline Sales Growth & -0.021 & -1.32 & 0.003 & 0.57 & -0.007 & -0.42 & -0.020 & -2.92 \\
\hline Beta & 0.000 & 0.00 & 0.000 & 0.00 & 16.184 & 0.46 & -0.323 & -0.05 \\
\hline Volatility & 0.234 & 2.37 & 0.162 & 1.89 & -0.025 & -0.28 & -0.156 & -3.83 \\
\hline Turnover & -0.002 & -1.99 & 0.000 & -0.02 & -0.004 & -2.51 & -0.002 & -1.68 \\
\hline Stock Return & 0.000 & -0.25 & 0.001 & 0.51 & -0.014 & -1.83 & -0.009 & -2.21 \\
\hline Year f.e. & No & & No & & Yes & & Yes & \\
\hline Firm f.e. & No & & No & & Yes & & Yes & \\
\hline Adj R-squared & $1.5 \%$ & & $0.4 \%$ & & $68.7 \%$ & & $59.0 \%$ & \\
\hline $\mathrm{N}$ & 2,982 & & 4,757 & & 4,684 & & 4,684 & \\
\hline
\end{tabular}


OLS regressions with robust and clustered standard errors at the firm and year level. In the first specification all variables are calculated as changes over a 3 -year period except for Sustainability Engagement and Sustainability Reporting Engagement. In the second specification all variables are calculated as changes over a 1-year period except for Sustainability Engagement and Sustainability Reporting Engagement. All variables are defined in the Appendix. 
Table 7: Sustainability Crisis, IR and Investor Clientele

\begin{tabular}{|c|c|c|c|c|c|c|c|c|}
\hline \multirow{2}{*}{$\begin{array}{l}\text { Dependent Variable } \\
\text { Parameter }\end{array}$} & \multicolumn{2}{|c|}{ 3-year IR change } & \multicolumn{2}{|c|}{ 1-year IR change } & \multicolumn{2}{|l|}{ IR } & \multicolumn{2}{|c|}{ LT Investor } \\
\hline & Estimate & $\mathrm{t}$ & Estimate & $\mathrm{t}$ & Estimate & $\mathrm{t}$ & Estimate & $\mathrm{t}$ \\
\hline Intercept & 5.569 & 7.40 & 1.768 & 8.48 & 41.319 & 0.95 & -26.860 & -2.40 \\
\hline Sustainability Crisis & 4.833 & 3.69 & 0.890 & 1.96 & & & & \\
\hline Sustainability Crisis After & & & & & 3.060 & 2.16 & & \\
\hline Predicted IR & & & & & & & 0.557 & 3.48 \\
\hline GRI & & & & & & & -0.021 & -0.43 \\
\hline Sustainability Report & & & & & & & -0.313 & -0.83 \\
\hline GRI & & & & & & & -0.575 & -1.41 \\
\hline EESG Performance & & & & & & & -0.007 & -0.93 \\
\hline Classified Board & & & & & & & 0.010 & 0.02 \\
\hline Staggered Board & & & & & & & 0.370 & 0.85 \\
\hline Supermajority Vote & & & & & & & 0.203 & 0.67 \\
\hline Firm Size & -0.204 & -0.14 & 0.247 & 0.36 & 0.438 & 0.34 & 0.353 & 0.78 \\
\hline Leverage & -0.003 & -0.11 & -0.019 & -0.78 & -0.037 & -1.14 & 0.029 & 1.62 \\
\hline $\mathrm{E} / \mathrm{P}$ & 0.052 & 1.34 & -0.016 & -0.73 & 0.069 & 2.05 & -0.108 & -5.54 \\
\hline РTB & -0.167 & -0.84 & -0.059 & -0.61 & 0.182 & 1.33 & -0.210 & -3.05 \\
\hline Dividend Yield & 0.539 & 1.60 & 0.363 & 2.23 & 0.232 & 0.84 & -0.224 & -1.97 \\
\hline Sales Growth & -0.026 & -1.59 & 0.003 & 0.49 & -0.009 & -0.56 & -0.016 & -2.29 \\
\hline Beta & 0.000 & 0.000 & 0.000 & 0.00 & 17.451 & 0.50 & -7.569 & -1.16 \\
\hline Volatility & 0.195 & 1.96 & 0.161 & 1.89 & -0.014 & -0.16 & -0.153 & -3.76 \\
\hline Turnover & -0.002 & -2.01 & 0.000 & 0.00 & -0.004 & -2.12 & 0.000 & 0.03 \\
\hline Stock Return & 0.000 & 0.18 & 0.001 & 0.53 & -0.013 & -1.72 & -0.003 & -0.72 \\
\hline Year f.e. & No & & No & & Yes & & Yes & \\
\hline Firm f.e. & No & & No & & Yes & & Yes & \\
\hline Adj R-squared & $1.1 \%$ & & $0.1 \%$ & & $68.7 \%$ & & $59.0 \%$ & \\
\hline $\mathrm{N}$ & 2,982 & & 4,757 & & 4,684 & & 4,684 & \\
\hline
\end{tabular}


OLS regressions with robust and clustered standard errors at the firm and year level. In the first specification all variables are calculated as changes over a 3-year period except for Sustainability Crisis. In the second specification all variables are calculated as changes over a 1-year period except for Sustainability Crisis. All variables are defined in the Appendix. 


\section{Table 8: IR and Investor Clientele}

\section{Panel A: Dedicated Investors}

\begin{tabular}{|c|c|c|c|c|c|c|c|c|c|c|}
\hline Dependent Variable & & & & & Dedicated In & stors & & & & \\
\hline Parameter & Estimate & $\mathrm{t}$ & Estimate & $\mathrm{t}$ & Estimate & $\mathrm{t}$ & Estimate & $\mathrm{t}$ & Estimate & $\mathrm{t}$ \\
\hline IR & 0.024 & 3.30 & 0.012 & 2.31 & 0.023 & 2.55 & & & & \\
\hline IR* PTB & & & & & 0.002 & 1.61 & & & & \\
\hline IR* Family Firm & & & & & -0.021 & -1.91 & & & & \\
\hline IR* Sin Firm & & & & & 0.016 & 2.11 & & & & \\
\hline IR* High IR Volatility & & & & & -0.026 & -2.69 & & & & \\
\hline Predicted IR - Engagement & & & & & & & 0.119 & 3.59 & & \\
\hline Predicted IR - Crisis & & & & & & & & & 0.060 & 0.81 \\
\hline Other firm controls & Yes & & Yes & & Yes & & Yes & & Yes & \\
\hline Year f.e. & Yes & & Yes & & Yes & & Yes & & Yes & \\
\hline Industry f.e. & Yes & & No & & Yes & & No & & No & \\
\hline Firm f.e. & No & & Yes & & No & & Yes & & Yes & \\
\hline
\end{tabular}




\section{Panel B: Transient Investors}

\begin{tabular}{|c|c|c|c|c|c|c|c|c|c|c|}
\hline Dependent Variable & & & & & Transient In & stors & & & & \\
\hline Parameter & Estimate & $\mathrm{t}$ & Estimate & $\mathrm{t}$ & Estimate & $\mathrm{t}$ & Estimate & $\mathrm{t}$ & Estimate & $\mathrm{t}$ \\
\hline IR & -0.007 & -1.15 & -0.011 & -2.39 & -0.005 & -0.66 & & & & \\
\hline $\mathrm{IR} * \mathrm{PTB}$ & & & & & -0.001 & -1.19 & & & & \\
\hline IR* Family Firm & & & & & 0.014 & 1.44 & & & & \\
\hline IR* Sin Firm & & & & & -0.025 & -2.72 & & & & \\
\hline IR* High IR Volatility & & & & & 0.030 & 2.38 & & & & \\
\hline Predicted IR - Engagement & & & & & & & -0.012 & -0.39 & & \\
\hline Predicted IR - Crisis & & & & & & & & & -0.234 & -2.57 \\
\hline Other firm controls & Yes & & Yes & & Yes & & Yes & & Yes & \\
\hline Year f.e. & Yes & & Yes & & Yes & & Yes & & Yes & \\
\hline Industry f.e. & Yes & & No & & Yes & & No & & No & \\
\hline Firm f.e. & No & & Yes & & No & & Yes & & Yes & \\
\hline
\end{tabular}

OLS regressions with robust and clustered standard errors at the firm and year level. The dependent variable in Panel A is calculated as the percentage of shares owned by dedicated investors and in Panel B as the percentage of shares owned by transient investors for a given firm and year. All specifications include all control variables included in the previous tables but they are not tabulated. The first and second specifications correspond to the fifth and seventh specifications respectively in Table 3. The third specification corresponds to the fifth specification in Table 5. The fourth and fifth specifications correspond to the fourth specification in Tables 6 and 7 respectively. All variables are defined in the Appendix. 
Table 9: Relevance, Reliability and Timeliness

\begin{tabular}{lrrrr}
\hline Parameter & Estimate & \multicolumn{1}{l}{$\mathrm{t}$} & Estimate & \multicolumn{1}{c}{$\mathrm{t}$} \\
\hline Intercept & 9.558 & 0.53 & 6.332 & 0.53 \\
IR & $\mathbf{0 . 0 3 1}$ & $\mathbf{2 . 6 7}$ & $\mathbf{0 . 0 2 0}$ & $\mathbf{1 . 9 0}$ \\
Audit & $\mathbf{1 . 3 9 6}$ & $\mathbf{0 . 9 8}$ & $\mathbf{1 . 2 1 2}$ & $\mathbf{0 . 7 6}$ \\
Timeliness & $\mathbf{0 . 1 0 0}$ & $\mathbf{1 . 9 8}$ & $\mathbf{0 . 0 6 7}$ & $\mathbf{1 . 4 4}$ \\
Firm controls & Yes & & Yes & \\
Year f.e. & Yes & & Yes & \\
Industry f.e. & Yes & & No & \\
Firm f.e. & No & & Yes & \\
Adj R-squared & $20.2 \%$ & & $60.9 \%$ & \\
N & 485 & & 485 & \\
\hline
\end{tabular}

OLS regressions with robust and clustered standard errors at the firm and year level. The dependent variable is LT Investor which is calculated as the difference between percentage of shares owned by dedicated and transient investors for a given firm and year. Audit is an indicator variable that takes the value of one if the firm's sustainability report is externally assured. Timeliness is the natural logarithm of max reporting lag plus one minus reporting lag between fiscal year end and date the report is issues publicly. All other variables are defined in the Appendix. 